\title{
Effects of stocking density on growth performance, survival rate and economic efficiency of Asian seabass (Lates calcarifer) cultured in earthen pond
}

\author{
Nhan T. Dinh \\ Faculty of Fisheries, Nong Lam University, Ho Chi Minh City, Vietnam
}

\begin{abstract}
ARTICLE INFO
Research Paper

Received: September 01, 2020

Revised: September 25, 2020

Accepted: October 23, 2020
\end{abstract}

\section{Keywords}

Asian seabass

Density

Earthen pond

Economic efficiency

Growth

\section{Corresponding author}

Dinh The Nhan

Email: dtnhan@hcmuaf.edu.vn

\begin{abstract}
This trial aimed to evaluate effects of stocking densities of $1-5$ fish $/ \mathrm{m}^{2}$ on growth performance, survival rate and economic efficiency of Asian seabass (Lates calcarifer) in earthen ponds. Fish with an initial length of $90.7 \pm 0.1 \mathrm{~mm}$ and weight of $20.8 \pm 0.1 \mathrm{~g} /$ fish and ponds with 600 $\mathrm{m}^{2}$ each and $1.5 \mathrm{~m}$ depth were used for this study. Experiment was designed with three treatments, including different stocking densities of 1, 3 and 5 fish $/ \mathrm{m}^{2}$. The fish was fed with pellete feed containing 43 - $44 \%$ crude protein. Water quality parameters including temperature, dissolved oxygen, $\mathrm{pH}$, salinity, transparency and ammonia concentration were measured once a week. Fish were sampled every 30 day intervals for length and weight measurement then for their growth estimation. Costs were recorded for economic efficiency estimation. Results showed that the water quality parameters were in suitable ranges for growth and development of Asian seabass. The final average length and weight of density $1 \mathrm{fish} / \mathrm{m}^{2}$ was significantly higher than those at 3 and $5 \mathrm{fish} / \mathrm{m}^{2}(P<$ 0.05). However, there was no significant difference on the fish growth in terms of daily length and weight gain, as well as survival rate and feed conversion ratio between different stocking densities. Asian seabass culture at 3 and 5 fish $/ \mathrm{m}^{2}$ resulted in a higher profit compared to at $1 \mathrm{fish} / \mathrm{m}^{2}$. The highest economic efficiency in terms of area pond was showed at $5 \mathrm{fish} / \mathrm{m}^{2}$ treatment.
\end{abstract}

Cited as: Dinh, N. T. (2020). Effects of stocking density on growth performance, survival rate and economic efficiency of Asian seabass (Lates calcarifer) cultured in earthen pond. The Journal of Agriculture and Development 19(5), 62-70. 


\title{
Ảnh hưởng của mật độ nuôi đến sinh trưởng, tỷ lệ sống và hiệu quả kinh tế của cá chẽm (Lates calcarifer) nuôi trong ao đất
}

\author{
Đinh Thế Nhân \\ Khoa Thủy Sản, Trường Đại Học Nông Lâm TP.HCM, TP. Hồ Chí Minh
}

\section{THÔNG TIN BÀI BÁO}

Bài báo khoa học

Ngày nhận: 01/09/2020

Ngày chỉnh sửa: 25/09/2020

Ngày chấp nhận: 23/10/2020

\section{Từ khóa}

Ao đất

Cá chẽm

Hiệu quả kinh tế

Mật độ

Tăng trưởng

\section{Tác giả liên hệ}

Đinh Thế Nhân

Email: dtnhan@hcmuaf.edu.vn

\section{TÓM TẮT}

Nghiên cứu này thử nghiệm đánh giá ảnh hưởng của các mật độ nuôi, từ $1-5 \mathrm{con} / \mathrm{m}^{2}$ lên tốc độ tăng trưởng, tỷ lệ sống và hiệu quả kinh tế của việc nuôi cá chẽm (Lates calcarifer) trong ao đất. Cá có chiều dài ban đầu $90,7 \pm 0,1 \mathrm{~mm}$ và khối lượng $20,8 \pm 0,1 \mathrm{~g} / \mathrm{con}$ được bố trí trong các ao đất có diện tích $600 \mathrm{~m}^{2} / \mathrm{ao}$, mực nước ao $1,5 \mathrm{~m}$. Thí nghiệm gồm 3 nghiệm thức tương ứng với 3 mật độ nuôi khác nhau: 1 , 3 và $5 \mathrm{con} / \mathrm{m}^{2}$. Cá được cho ăn thức ăn viên với hàm lượng đạm thô từ $43-44 \%$. Định kỳ 1 tuần/lần thu mẫu nước để đo nhiệt độ, ôxy hòa tan, $\mathrm{pH}$, độ mặn, độ trong và ammonia. Định kỳ 30 ngày/lần tiến hành thu mẫu cá, đo chiều dài và cân khối lượng để xác định tăng trưởng. Các chi phí được ghi nhận để tính toán hiệu quả kinh tế. Kết quả cho thấy các yếu tố môi trường thích hợp cho sự sinh trưởng và phát triển của cá chẽm. Chiều dài và khối lượng trung bình của cá khi thu hoạch ở mật độ $1 \mathrm{con} / \mathrm{m}^{2}$ là cao hơn so với 3 và $5 \mathrm{con} / \mathrm{m}^{2}(P<0,05)$. Tuy nhiên, mật độ nuôi không ảnh hưởng rõ rệt đến các chỉ tiêu sinh trưởng như tăng trưởng theo ngày về chiều dài và khối lượng, cũng như tỷ lệ sống và hệ số chuyển đổi thức ăn. Cá được nuôi ở mật độ 3 và $5 \mathrm{con} / \mathrm{m}^{2}$ cho hiệu quả kinh tế cao hơn so với mật độ $1 \mathrm{con} / \mathrm{m}^{2}$. Nghiệm thức 5 $\mathrm{con} / \mathrm{m}^{2}$ thì cho lợi nhuận trên tính trên diện tích nuôi là cao nhất.

\section{1. Đặt Vấn Đề}

Cá chẽm, còn được gọi là cá vược, là loài cá rộng muối được phân bố rộng ở vùng Ấn Độ Dương - Tây Thái Bình Dương, từ Vịnh Ả Rập tới Trung Quốc, Đài Loan và Bắc Australia (FAOFAD, 2020). Sản lượng cá chẽm nuôi của 5 nước gồm Đài Loan, Malaysia, Thái Lan, Indonesia và Australia đã gia tăng từ 10.000 tấn vào năm 1991 lên khoảng 95.000 tấn vào năm 2018, với tốc độ tăng trưởng từ năm 2006 đến 2016 là 170,6\% (GAA, 2016). Cá chẽm có thể được nuôi trong ao nước lợ hay nước ngọt và lồng lưới cố định hay nổi trong các thủy vực ven biển; tuy nhiên, hình thức nuôi lồng phổ biến hơn. Thức ăn cho nuôi cá chẽm là cá tạp và thức ăn công nghiệp (FAO-FAD, 2020).
Ở Việt Nam, cá chẽm phân bố ở phía Đông vịnh Bắc bộ và vùng biển Trung bộ. Chúng đã và đang là đối tượng cá biển được nuôi khá thành công ở nhiều địa phương. Năm 2005, Việt Nam đã nhập vài chục triệu con giống từ Thái Lan để thả nuôi ở các đầm, hồ ven biển và cửa sông của các tỉnh phía Nam cho đến các tỉnh phía Bắc. Hiện nay, nước ta cũng đã làm chủ được công nghệ sản xuất giống nhân tạo, đáp ứng cả về số lượng và chất lượng con giống cho người nuôii, và mở ra triển vọng cho việc phát triển nghề nuôi cá chẽm quy mô công nghiệp. Nuôi cá chẽm ở Việt Nam cũng bao gồm nuôi trong ao nước lợ và lồng lưới trong các thủy vực ven biển. Tuy nhiên, ở Đồng bằng sông Cửu Long (ĐBSCL) mô hình nuôi cá chẽm trong ao nước lợ là chủ yếu (Ly \& ctv., 2016). Cho đến nay, các nghiên cứu trên cá 
chẽm (Lates calcarifer), đặc biệt về kỹ thuật nuôi, còn rất hạn chế. Nghiên cứu này nhằm đánh giá ảnh hưởng của các mật độ nuôi từ $1-5 \mathrm{con} / \mathrm{m}^{2}$ đến sinh trưởng và hiệu quả kinh tế của cá chẽm được nuôi trong ao đất.

\section{Vật Liệu và Phương Pháp Nghiên Cứu}

\section{1. Đối tượng}

Cá chẽm (Lates calcarifer) thử nghiệm có khối lượng trung bình là $20,8 \pm 0,1 \mathrm{~g}$ và chiều dài trung bình là 90,7 $\pm 0,1 \mathrm{~mm}$. Trước khi tiến hành bố trí thí nghiệm, cá giống được chọn lựa có kích cỡ tương đối đồng đều, ngoại hình đẹp, không có dấu hiệu bệnh và không bị sây sát.

\subsection{Bố trí thí nghiệm}

Thử nghiệm bao gồm ba nghiệm thức (NT) ứng với ba mật độ nuôi khác nhau: 1 (NT1), 3 (NT2) và $5 \mathrm{con} / \mathrm{m}^{2}$ (NT3), mỗi NT được lặp lại ba lần và được bố trí theo kiểu hoàn toàn ngẫu nhiên trong 9 ao đất, diện tích $600 \mathrm{~m}^{2} /$ ao và độ sâu mực nước trung bình là $1,5 \mathrm{~m}$.

Ao thí nghiệm được tháo cạn và tiến hành xịt rửa sạch bùn đáy ao. Vôi sống $(\mathrm{CaO})$ được bón đều khắp ao với lượng $10 \mathrm{~kg} / 100 \mathrm{~m}^{2}$. Sau đó lấy nước vào đầy ao qua túi lọc có mắt lưới $1 \mathrm{~mm}$. Nguồn nước có độ mặn dao động từ 5-25\%o theo mùa trong vụ nuôi. Sau khi gây màu nước, cá được thả vào các ao thí nghiệm theo các mật độ ứng với từng nghiệm thức vào buổi sáng. Cá thí nghiệm được nuôi trong 240 ngày.

Cá được cho ăn thức ăn viên nổi của Công ty Ocialis với thành phần sinh hóa như sau: độ ẩm $12 \%$, đạm thô $43-44 \%$, xơ thô $3 \%$, canxi (min - max) 2,5 - 3,5\%. Cách 7 ngày bổ sung khoáng chất và vitamin $\mathrm{C}$ bằng cách trộn đều vào thức ăn (Bảng 1).

Cá được cho ăn 2 lần/ngày vào lúc 5 giờ và 18 giờ với mức thỏa mãn. Thức ăn được cung cấp từ từ vào khung chắn thức ăn, kéo dài khoảng 30 phút đến khi cá ngừng ăn, ở mỗi lần cho ăn. Sau mỗi bữa ăn, tiến hành vớt thức ăn thừa, sấy khô và ghi nhận lượng thức ăn cá đã ăn.

Ao được tăng cường ôxy bằng thiết bị ống khuếch tán khí (airotube). Thường xuyên thay nước ao với tần suất khoảng 1 tuần/lần ở giai đoạn cá còn nhỏ và 3 - 5 ngày/lần ở giai đoạn cá lớn với mức thay khoảng 30 - 40\% lượng nước ao, kết hợp sử dụng chế phẩm vi sinh để xử lý môi trường ao nuôi.

\subsection{Phương pháp phân tích}

\subsubsection{Các chỉ tiêu tăng trưởng}

Trước khi bố trí thí nghiệm bắt ngẫu nhiên 30 cá cân khối lượng bằng cân điện tử với sai số $1 \mathrm{~g}$ và đo chiều dài từng cá thể với thước kẻ có vạch $1 \mathrm{~mm}$. Định kỳ 30 ngày tiến hành thu ngẫu nhiên $30 \mathrm{con} / \mathrm{ao}$ để tính khối lượng và chiều dài trung bình của cá thí nghiệm. Vào cuối vụ nuôi tiến hành thu toàn bộ cá trong ao để thực hiện cân, đo và đếm số lượng cá để tính các chỉ tiêu tăng trưởng, tỉ lệ sống và hệ số chuyển đổi thức ăn, theo các công thức sau:

Tăng trưởng chiều dài theo ngày (daily length gain, DLG):

$\operatorname{DLG}(\mathrm{mm} /$ ngày $)=\left(\mathrm{L}_{2}-\mathrm{L}_{1}\right) /\left(\mathrm{T}_{2}-\mathrm{T}_{1}\right)$

Tăng trưởng khối lượng theo ngày (daily weight gain, DWG):

DWG $(\mathrm{g} /$ ngày $)=\left(\mathrm{W}_{2}-\mathrm{W}_{1}\right) /\left(\mathrm{T}_{2}-\mathrm{T}_{1}\right)$

Tỉ lệ sống (survival rate, $\mathrm{SR}$ ):

$\operatorname{SR}(\%)=100 *\left(\mathrm{~N}_{\mathrm{c}} / \mathrm{N}_{\mathrm{d}}\right)$

Hệ số chuyển đổi thức ăn (feed conversion ratio, FCR):

$\mathrm{FCR}=\mathrm{W}_{\mathrm{ta}} /\left(\mathrm{W}_{\mathrm{c}}-\mathrm{W}_{\mathrm{d}}\right)$

Trong đó:

$\mathrm{W}_{1}$ và $\mathrm{W}_{2}$ : Khối lượng cá $(\mathrm{g})$ trung bình tại thời điểm $\mathrm{T}_{1}$ và $\mathrm{T}_{2}$

$\mathrm{L}_{1}$ và $\mathrm{L}_{2}$ : Chiều dài cá $(\mathrm{cm})$ trung bình tại thời điểm $\mathrm{T}_{1}$ và $\mathrm{T}_{2}$

$\mathrm{N}_{\mathrm{d}}$ và $\mathrm{N}_{\mathrm{c}}$ : Số lượng cá (con) ban đầu và cuối thí nghiệm

$\mathrm{W}_{\mathrm{ta}}$ : Tổng khối lượng thức ăn $(\mathrm{kg})$ đã sử dụng $\mathrm{W}_{\mathrm{d}}$ và $\mathrm{W}_{\mathrm{c}}$ : Tổng khối lượng cá $(\mathrm{kg})$ khi bắt đầu và kết thúc thí nghiệm

\subsubsection{Hiệu quả kinh tế}

Hiệu quả kinh tế được phân tích dựa trên tổng chi phí và tổng doanh thu để tính toán các chỉ tiêu lợi nhuận ròng cho 1 ha/vụ nuôi và tỷ suất lợi nhuận trên tổng chi phí (\%) (Do \& Dang, 2010).

\subsubsection{Các yếu tố môi trường nước}

Các yếu tố môi trường bao gồm nhiệt độ (dùng nhiệt kế thủy ngân), ôxy hòa tan, pH (dùng test 
Bảng 1. Các loại thức ăn sử dụng trong thí nghiệm

\begin{tabular}{ccccc}
\hline TT & Loại thức ăn & Kích cỡ viên $(\mathrm{mm})$ & Độ đạm $(\%)$ & Cỡ cá $(\mathrm{g})$ \\
\hline 1 & NUTRILIS P2 & 3 & 44 & $10-50$ \\
2 & NUTRILIS P3 & 5 & 43 & $50-150$ \\
3 & NUTRILIS P4 & 7 & 43 & $150-400$ \\
4 & NUTRILIS P5 & 10 & 43 & $400-1000$ \\
\hline
\end{tabular}

kit của tập đoàn $\mathrm{CP}$ ) được đo vào lúc 7 giờ và 15 giờ với tần suất 1 tuần/lần; độ mặn (dùng khúc xạ kế Atogo HHR 2N), ammonia (dùng test kit của tập đoàn $\mathrm{CP}$ ) và độ trong nước (dùng đĩa secchi) được đo với tần suất là 1 tuần/lần. Các yếu tố môi trường còn được đo vào những ngày thu mẫu cá.

\subsection{Xử lý số liệu}

Các phân tích thống kê được thực hiện với các phần mềm Microsoft Excel 2010 và SPSS 20.0 for Window. Các số liệu được phân tích phương sai (ANOVA) một yếu tố ở mức ý nghĩa $P=0,05$, và khi các ảnh hưởng được tìm thấy là có ý nghĩa, LSD được sử dụng để xác định các khác biệt cho từng cặp nghiệm thức. Các số liệu \% được chuyển đổi thành $\operatorname{arsin} \sqrt{ }$ trước khi phân tích. Các số liệu ở mục Kết Quả và Thảo Luận được trình bày dưới dạng trung bình \pm độ lệch chuẩn.

\section{Kết Quả và Thảo Luận}

\subsection{Sự biến động của các yếu tố chất lượng nước}

Nhìn chung hầu hết các yếu tố chất lượng nước của 3 nghiệm thức (NT) có sự thay đổi theo thời gian nuôi, tuy nhiên xu hướng thay đổi của $3 \mathrm{NT}$ là khá giống nhau và không có sự khác biệt đáng kể (Hình 1). Trong đó:

Nhiệt độ có xu hướng giảm dần từ đầu vụ nuôi cho đến ngày nuôi thứ 150 . Nhiệt độ trung bình trong các ao biến động từ $27,7-31,2^{\circ} \mathrm{C}$ là không lớn và không có sự khác biệt ở cả ba nghiệm thức trong suốt thời gian nuôi.

Hàm lượng ôxy hòa tan (DO) trung bình dao động từ 3,4 - 4,3 mg/L; biến động nhiều nhất ở NT3, tiếp theo là NT2 và NT1, không có sự khác biệt đáng kể giữa các NT vì lượng ôxy được cung cấp tương ứng với mật độ nuôi. Quan sát những thời điểm có hàm lượng $\mathrm{DO}<4 \mathrm{mg} / \mathrm{L}$ thấy cá vẫn hoạt động và ăn bình thường.

pH trung bình dao động 7,2 - 7,7. pH ở cả 3 nghiệm thức tăng dần từ ngày đầu tiên tới ngày thứ 90 là do càng về sau lượng tảo trong các ao nuôi càng phát triển. Ở mật độ càng cao, tảo phát triển nhiều hơn nên $\mathrm{pH}$ biến động lớn hơn.

Độ mặn trung bình ở 3 nghiệm thức có sự biến dộng lớn, từ 5,0 - 25,0\%o. Sự biến động độ mặn diễn ra từ từ theo mùa vụ nên không ảnh hưởng đến sinh lý của cá nuôi vì cá chẽm là loài rộng muối.

Độ trong trung bình của 3 nghiệm thức biến động từ $24-48 \mathrm{~cm}$. Độ trong của các ao nuôi có xu hướng giảm dần về cuối vụ nuôi do sự phát triển mạnh của tảo.

Hàm lượng $\mathrm{NH}_{3}$ trung bình trong các ao nuôi dao động từ $0,1-0,28 \mathrm{mg} / \mathrm{L}$ và không có sự khác biệt giữa các nghiệm thức thí nghiệm. Hàm lượng $\mathrm{NH}_{3}$ tăng dần và đạt cao nhất ở ngày nuôi thứ 60, sau đó có xu hướng giảm dần đến cuối đợt thí nghiệm do tăng cường thay nước.

\subsection{Tăng trưởng}

\subsubsection{Chiều dài trung bình}

Sau 30 ngày nuôi, cá ở NT2 có AL lớn nhất và khác biệt có ý nghĩa thống kê $(P<0,05)$ so với các nghiệm thức còn lại. Nhìn chung, từ ngày thứ 60 đến cuối thí nghiệm, cá ở NT1 luôn có AL lớn nhất, kế đến là NT2 và thấp nhất là NT3. Từ ngày thứ 60 đến $120, \mathrm{AL}$ của cá ở NT1 là không khác biệt so với NT2 nhưng khác biệt có ý nghĩa thống kê so với NT3. Từ ngày thứ 150 đến cuối thí nghiệm, AL của cá ở NT1 là khác biệt có ý nghĩa thống kê so với các nghiệm thức còn lại. Trong khi đó, AL của cá ở NT2 khác biệt không có ý nghĩa thống kê so với NT3 từ ngày thứ 150 đến cuối thí nghiệm (Bảng 2).

\subsubsection{Tăng trưởng theo ngày về chiều dài}

Nhìn chung, DLG của cá chẽm ở cả 3 nghiệm thức giảm dần theo thời gian. DLG của cá giảm mạnh vào ngày thứ 120 có thể là do sự biến động của môi trường nuôi đã có ảnh hưởng bất lợi đến 

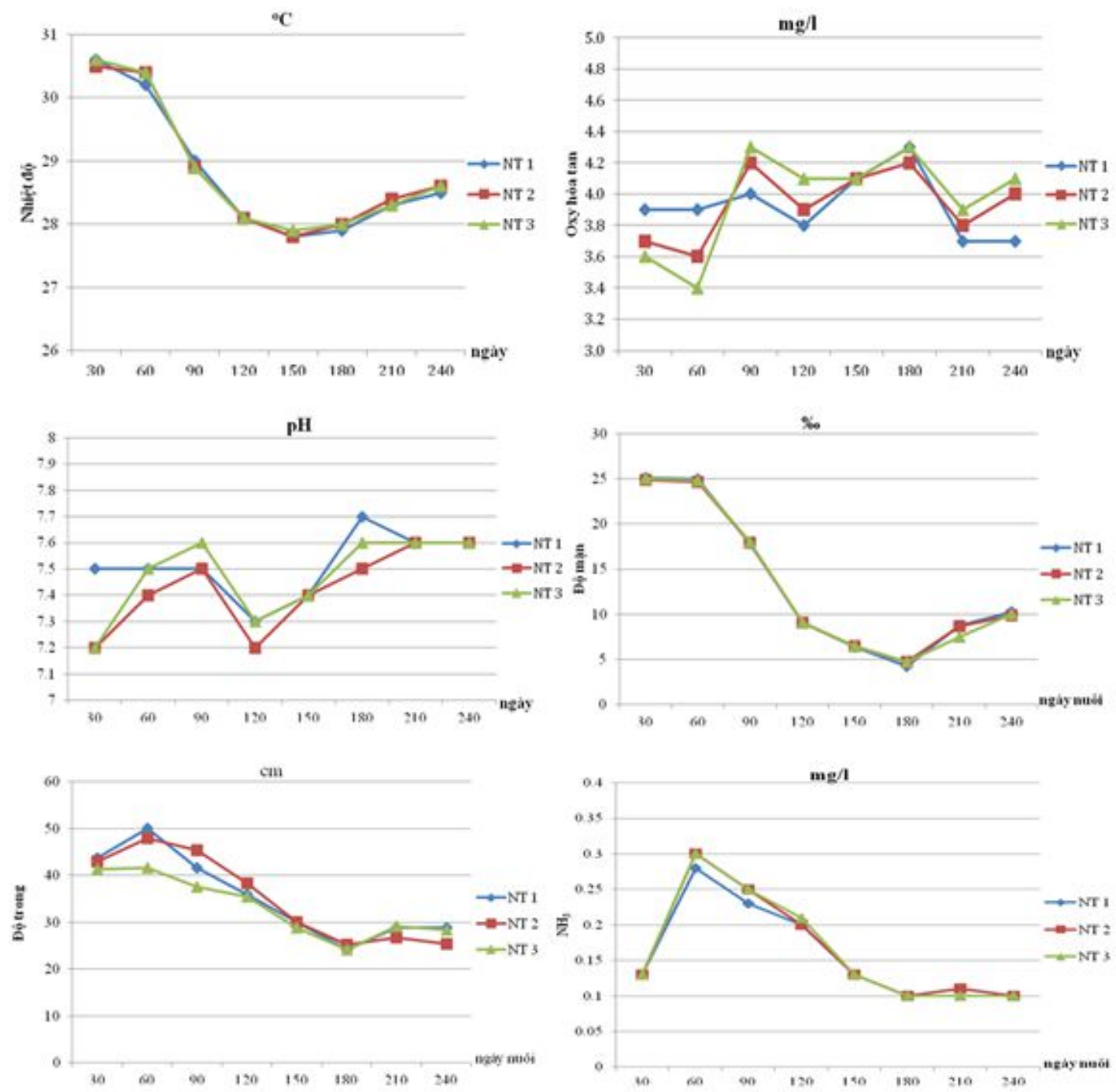

Hình 1. Biến động các yếu tố chất lượng nước của 3 nghiệm thức theo thời gian nuôi.

Bảng 2. Chiều dài trung bình $(\mathrm{AL}, \mathrm{mm})$ của cá chẽm theo thời gian nuôi

\begin{tabular}{cccc}
\hline Ngày nuôi & NT1 & NT2 & NT3 \\
\hline 0 & $90,7^{\mathrm{a}} \pm 0,1$ & $90,8^{\mathrm{a}} \pm 0,1$ & $90,7^{\mathrm{a}} \pm 0,1$ \\
30 & $151,5^{\mathrm{a}} \pm 17,5$ & $165,6^{\mathrm{b}} \pm 10,3$ & $150,3^{\mathrm{a}} \pm 9,7$ \\
60 & $213,7^{\mathrm{b}} \pm 15,4$ & $210,0^{\mathrm{b}} \pm 15,5$ & $204,9^{\mathrm{a}} \pm 11,5$ \\
90 & $246,1^{\mathrm{b}} \pm 14,9$ & $247,7^{\mathrm{b}} \pm 11,9$ & $237,8^{\mathrm{a}} \pm 13,0$ \\
120 & $263,8 \mathrm{~b}^{\mathrm{b}} \pm 13,8$ & $260,2^{\mathrm{ab}} \pm 13,6$ & $258,0^{\mathrm{a}} \pm 18,5$ \\
150 & $301,6^{\mathrm{c}} \pm 12,8$ & $292,9^{\mathrm{b}} \pm 16,0$ & $285,6^{\mathrm{a}} \pm 15,5$ \\
180 & $329,9^{\mathrm{b}} \pm 23,4$ & $309,3^{\mathrm{a}} \pm 24,1$ & $305,7^{\mathrm{a}} \pm 18,0$ \\
210 & $349,9^{\mathrm{b}} \pm 23,4$ & $328,1^{\mathrm{a}} \pm 24,7$ & $324,9^{\mathrm{a}} \pm 18,6$ \\
240 & $364,9^{\mathrm{b}} \pm 23,4$ & $343,1^{\mathrm{a}} \pm 24,7$ & $339,9^{\mathrm{a}} \pm 18,7$ \\
\hline
\end{tabular}

Các giá trị trên cùng một hàng có các chữ ký tự giống nhau thì khác biệt không có ý nghĩa thống kê $(P>0,05)$. 
Bảng 3. Khối lượng trung bình $(\mathrm{AW}, \mathrm{g})$ của cá chẽm theo thời gian

\begin{tabular}{cccc}
\hline Ngày nuôi & NT1 & NT2 & NT3 \\
\hline 0 & $20,8^{\mathrm{a}} \pm 0,1$ & $20,9^{\mathrm{a}} \pm 0,1$ & $20,8^{\mathrm{a}} \pm 0,1$ \\
30 & $53,9^{\mathrm{a}} \pm 8,5$ & $57,6^{\mathrm{a}} \pm 12,3$ & $51,0^{\mathrm{a}} \pm 2,9$ \\
60 & $140,8^{\mathrm{a}} \pm 8,9$ & $135,7^{\mathrm{a}} \pm 19,9$ & $123,3^{\mathrm{a}} \pm 3,3$ \\
90 & $207,3^{\mathrm{a}} \pm 8,5$ & $179,8^{\mathrm{a}} \pm 21,2$ & $181,1^{\mathrm{a}} \pm 10,2$ \\
120 & $331,6^{\mathrm{a}} \pm 22,9$ & $277,6^{\mathrm{a}} \pm 38,4$ & $282,8^{\mathrm{a}} \pm 13,0$ \\
150 & $408,8^{\mathrm{a}} \pm 67,2$ & $339,0^{\mathrm{a}} \pm 43,8$ & $348,1^{\mathrm{a}} \pm 40,3$ \\
180 & $542,2^{\mathrm{b}} \pm 68,4$ & $433,9^{\mathrm{ab}} \pm 37,7$ & $427,9^{\mathrm{a}} \pm 9,1$ \\
210 & $692,2^{\mathrm{b}} \pm 32,0$ & $609,3^{\mathrm{a}} \pm 16,5$ & $572,1^{\mathrm{a}} \pm 13,6$ \\
240 & $920,0^{\mathrm{b}} \pm 38,4$ & $829,3^{\mathrm{a}} \pm 28,9$ & $789,9^{\mathrm{a}} \pm 23,5$ \\
\hline
\end{tabular}

Các giá trị trên cùng một hàng có các chữ ký tự giống nhau thì khác biệt không có ý nghĩa thống kê $(P>0,05)$.

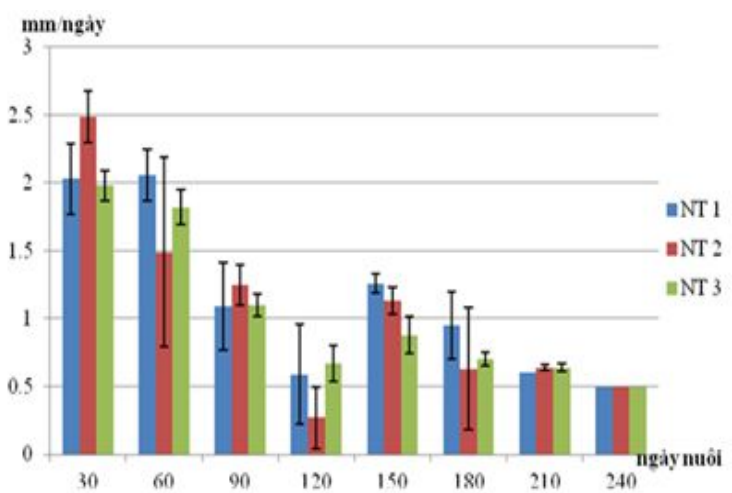

Hình 2. Tăng trưởng theo ngày về chiều dài của cá chẽm.

tăng trưởng về chiều dài của cá. Sau khi được tăng cường thay nước, DLG của cá đã có sự hồi phục (Hình 2). DLG của cá ở 3 nghiệm thức có sự khác biệt có ý nghĩa thống kê $(P<0,05)$ ở các lần lấy mẫu vào các ngày thứ 30,60 và 150 , và khác biệt không có ý nghĩa thống kê $(P>0,05)$ ở những lần lấy mẫu khác.

\subsubsection{Khối lượng trung bình}

Nhìn chung, cá ở cả 3 nghiệm thức có sự tăng trưởng đều về khối lượng theo thời gian nuôi; trong đó cá ở NT1 có AW lớn nhất, kế đến là NT2 và thấp nhất ở NT3. Tuy nhiên, từ ngày thứ 30 đến 150, AW của cá ở cả 3 nghiệm thức khác biệt không có ý nghĩa thống kê; từ ngày thứ 180 đến cuối thí nghiệm vào ngày thứ 240, AW của cá ở NT1 đã có sự gia tăng vượt trội và khác biệt có ý nghĩa thống kê so với 2 nghiệm thức còn lại. AW của cá ở NT2 và NT3 khác biệt không có ý nghĩa thống kê từ ngày thứ 150 (Bảng 3).

\subsubsection{Tăng trưởng theo ngày về khối lượng}

DWG của cá chẽm ở cả 3 nghiệm thức có khuynh hướng tăng dần nhưng không đều theo thời gian nuôi (Hình 3). Tuy nhiên, sự biến động của DWG của cá ở NT1 là ít hơn so với các nghiệm còn lại. Nhìn chung, DWG của cá ở NT1 là cao nhất, kế đến là NT2 và thấp nhất là NT3 nhưng sự khác biệt DWG của cá ở cả 3 nghiệm thức là không có ý nghĩa thống kê.

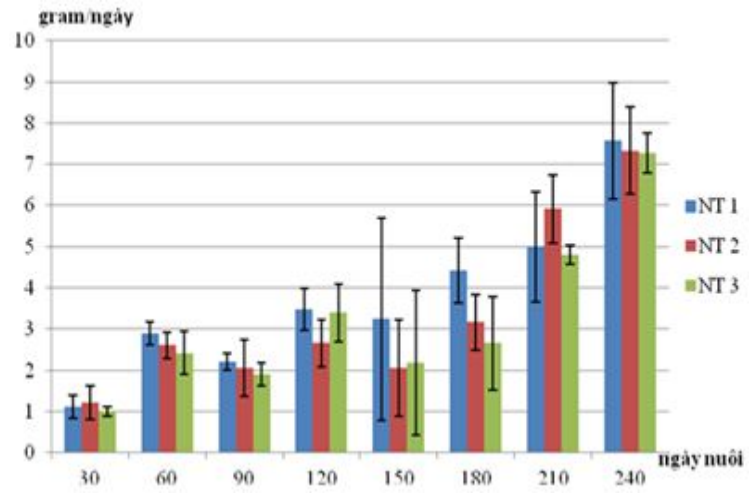

Hình 3. Tăng trưởng theo ngày về khối lượng của cá chẽm.

\subsection{Tỷ lệ sống ( $\mathrm{SR})$ và hệ số chuyển đổi thức ăn (FCR)}

\subsubsection{Tỷ lệ sống}

Tỷ lệ sống của cá có khuynh hướng giảm dần từ NT1 đến NT2 và NT3 (lần lượt là 95,57, 92,03 và $88,43 \%$ ) (Hình 4). Tuy nhiên, sự khác biệt về SR giữa 3 nghiệm thức là không có ý nghĩa thống kê $(P>0,05)$. 
Bảng 4. Các chi phí, doanh thu, lợi nhuận và hiệu quả đồng vốn của nuôi cá chẽm với các mật độ khác nhau

\begin{tabular}{lcccl}
\hline Các thông số & NT1 & NT2 & NT3 & Ghi chú \\
\hline Cá giống & 9.000 & 27.000 & 45.000 & 5.000 đ/con \\
Thức ăn & 63.345 & 172.942 & 270.393 & 26.000 đ/kg \\
Lao động, quản lý & 16.000 & 16.000 & 16,000 & \\
Điện/nhiên liệu & 8.000 & 16.000 & 24.000 & Điện sục khí, thay nước \\
Thuốc, hóa chất & 5.000 & 10.000 & 15.000 & Men. Vitamin. vôi... \\
Khấu hao & 5.000 & 7.500 & 10.000 & Máy móc, thiết bị \\
Tổng chi phí & 106.345 & 249.442 & 380.393 & \\
Giá thành & 67,2 & 60,5 & 60,5 & Tính trên 1 kg cá \\
Tổng doanh thu & 115.529 & 300.878 & 458.931 & \\
Lợi nhuận & 9.184 & 51.436 & 78.538 & Tính cho $1800 \mathrm{~m}^{2}$ \\
Lợi nhuận & 51.020 & 285.758 & 436.324 & Tính cho 1 ha \\
Tỷ suất lợi nhuận $(\%)$ & 8,64 & 20,62 & 20,65 & Tính trên tổng chi phí \\
\hline
\end{tabular}

Tính trên mỗi NT có tổng diện tích nuôi $1800 \mathrm{~m}^{2}$ (đơn vị tính 1.000 đ)

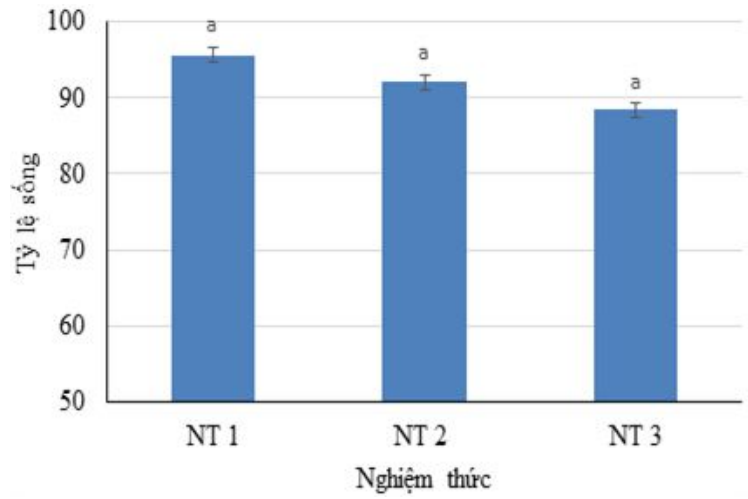

Hình 4. Tỷ lệ sống $(\%)$ của cá chẽm ở 3 nghiệm thức.

\subsubsection{Hệ số chuyển đổi thức ăn}

FCR của cá có khuynh hướng tăng dần từ NT1 đến NT2 và NT3 (lần lượt là $1,54,1,61$ và 1,65 ) (Hình 5). Tuy nhiên, sự khác biệt về FCR giữa 3 nghiệm thức là không có ý nghĩa thống kê.

\subsection{Hiệu quả kinh tế}

Sự gia tăng mật độ nuôi đã làm gia tăng sản lượng và tổng chi phí. Tuy nhiên, giá thành lại giảm theo mật độ nuôi do tận dụng được trang thiết bị, lao động, ... khi mật độ nuôi tăng lên. Lợi nhuận và tỷ suất lợi nhuận cũng gia tăng theo mật độ nuôi. Lợi nhuận của NT2 đạt 5,6 lần so với $\mathrm{NT} 1$, và của $\mathrm{NT} 3$ đạt 1,5 lần so với $\mathrm{NT} 2$ và 8,6 lần so NT1. Tương tự, Tỷ suất lợi nhuận của $\mathrm{NT} 2$ và NT3 tương đương và gấp 2,4 lần so với

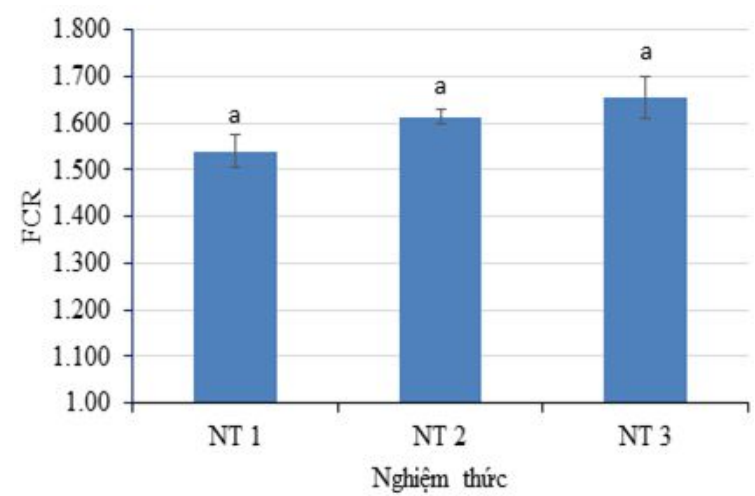

Hình 5. Hệ số chuyển đổi thức ăn (FCR) của cá chẽm .

\section{NT1 (Bảng 4).}

\subsection{Thảo luận}

Các yếu tố môi trường ở 3 nghiệm thức có sự biến động tương tự nhau theo thời gian nuôi. Sự biến động này, ngoài những quá trình sinh hóa xảy ra trong ao nuôi, còn do tác động của thời tiết và hoạt động quản lý của con người. Theo Boyd (1998), các yếu tố môi trường lý tưởng cho cá nhiệt đới bao gồm nhiệt độ từ $25-32^{\circ} \mathrm{C}$, ôxy hòa $\tan (\mathrm{DO}) \geq 4 \mathrm{mg} / \mathrm{L}, \mathrm{pH}$ từ $7-9$, ammonia $\left(\mathrm{NH}_{3}-\mathrm{N}\right)<0,1 \mathrm{mg} / \mathrm{L}$ và độ trong từ $30-45 \mathrm{~cm}$. Theo Kungvankij \& ctv. (1986), trong tự nhiên cá chẽm là loài rộng muối (euryhaline) và di cư xuôi dòng (catadromous) - cá sinh trưởng trong nước ngọt và di lưu ra nước mặn đẻ trứng - nên có thể chịu đựng được khoảng dao động của độ 
mặn rộng, từ 0 - 36\%o và độ mặn thích hợp cho sinh trưởng là 10 - 30\%o. Như vậy, hầu hết các yếu tố môi trường ở cả 3 nghiệm thức đều nằm trong khoảng thích hợp cho cá nói chung (Boyd, 1998) và cho cá chẽm nói riêng (Kungvankij \& ctv., 1986).

Cá thí nghiệm ở cả 3 nghiệm thức có sự tăng trưởng đều đặn cả về chiều dài và khối lượng. Ưu thế tăng trưởng về chiều dài $(\mathrm{AL})$ và khối lượng (AW) của cá ở NT1 chỉ thể hiện rõ từ ngày thứ 150 và 180 cho đến cuối thí nghiệm, một cách tương ứng; trong khi đó $\mathrm{AL}$ và $\mathrm{AW}$ của cá ở NT2 và NT3 là tương đương nhau (Bảng 2 và 3 ). Tăng trưởng theo ngày về chiều dài (DLG) của cá thí nghiệm ở cả 3 nghiệm thức là tương đương nhau từ ngày thứ 180 , và tăng trưởng theo ngày về khối lượng (DWG) của cá ở cả 3 nghiệm thức là tương đương nhau trong suốt thí nghiệm. Như vậy, trong phạm vi mật độ $1-5 \mathrm{con} / \mathrm{m}^{2}$, ảnh hưởng của mật độ đến sinh trưởng của cá thí nghiệm là không rõ rệt. Daet (2019) cũng tìm thấy mật độ không có ảnh hưởng đến sinh trưởng của cá chẽm nuôi trong giai đặt trong cùng một ao đất. Tăng trưởng của cá trong thử nghiệm cũng tương đương về $\mathrm{AW}$ và $\mathrm{DWG}$ nhưng thấp hơn về SGR so với cá chẽm nuôi lồng của Anil \& ctv. (2010). Tỷ lệ sống (SR) của cá trong thử nghiệm này đạt cao $(88,43-95,57 \%)$ và hệ số chuyển đổi thức ăn (FCR) đạt thấp $(1,54-1,65)$, tốt hơn so với SR $(66 \%)$ và $\mathrm{FCR}(2,5)$ của cá chẽm muôi ao với thức ăn viên (Hajirezaee \& ctv. (2015).

So sánh năng suất qui đổi từ thử nghiệm với cùng kích cỡ giống thả $(8-10 \mathrm{~cm})$, mật độ nuôi ( $5 \mathrm{con} / \mathrm{m} 2)$ và thời gian nuôi ( 8 tháng) thì năng suất đạt được của thử nghiệm (34,93 tấn/ha) là cao hơn của các mô hình nuôi ở ĐBSCL (33,3 tấn/ha) theo báo cáo nhóm tác giả Ly \& ctv. (2016). Giá thành nuôi cá chẽm có khuynh hướng gia tăng theo thời gian, trung bình 42.860 d/kg (ở Khánh Hòa) vào năm 2008 (Nguyen, 2009) lên trung bình 58.400đ/kg (ở ĐBSCL) vào năm 2013 (Ly \& ctv., 2016) và $60.395-67.210$ đ/kg (của thử nghiệm này, 2018). Trong điều kiện thử nghiệm, do lợi nhuận tăng theo mật độ nuôi (từ 51 triệu đ/ha ở mật độ $1 \mathrm{con} / \mathrm{m}^{2}$, lên 286 triệu đ/ha ở mật độ $3 \mathrm{con} / \mathrm{m}^{2}$ và 436 triệu đ/ha ở mật độ 5 $\mathrm{con} / \mathrm{m}^{2}$ ) và tỷ suất lợi nhuận ở mật độ 3 và 5 con $/ \mathrm{m} 2$ tương đương nhau $(21 \%)$ cao hơn mật độ $1 \mathrm{con} / \mathrm{m}^{2}(9 \%)$, nên nuôi cá chẽm ở mật độ 3 và $5 \mathrm{con} / \mathrm{m}^{2}$ sẽ cho hiệu quả kinh tế cao so với mật độ $1 \mathrm{con} / \mathrm{m}^{2}$.

\section{Kết Luận}

Các yếu tố môi trường biến động theo thời gian nuôi nhưng ở giới hạn thích hợp cho sự sinh trưởng và phát triển của cá chẽm.

Chiều dài và khối lượng trung bình của cá khi thu hoạch ở mật độ $1 \mathrm{con} / \mathrm{m}^{2}$ là cao hơn so với 3 và $5 \mathrm{con} / \mathrm{m}^{2}$. Tuy nhiên sự khác biệt của các chỉ tiêu sinh trưởng như tăng trưởng theo ngày về chiều dài và khối lượng, tỷ lệ sống, và hệ số chuyển đổi thức ăn của cá ở các NT là không rõ rệt.

Nuôi cá chẽm ở mật độ 3 và $5 \mathrm{con} / \mathrm{m}^{2}$ cho hiệu quả kinh tế cao hơn so với các mật độ $1 \mathrm{con} / \mathrm{m}^{2}$. Lợi nhuận tính trên diện tích ở mật độ $5 \mathrm{con} / \mathrm{m}^{2}$ là cao nhất.

Đề xuất tiến hành thử nghiệm nuôi ở những mật độ cao hơn (trên $5 \mathrm{con} / \mathrm{m}^{2}$ ) để xác định ảnh hưởng của mật độ đến sinh trưởng và hiệu quả kinh tế của hoạt động nuôi cá chẽm trong ao đất.

\section{Tài Liệu Tham Khảo (References)}

Anil, M. K., Santhosh, B., Jasmine, S., Saleela, K. N., George, R. M., Kingsly, H. J., Unnikrishnan, C., Rao, G. H., \& Rao, G. S. (2010). Growth performance of the seabass (Lates calcarifer) in sea cage at Vizhinjam Bay along the south-west coast of India. Indian Journal of Fisheries 57(4), 65-69.

Boyd, C. E. (1998). Water Quality for Pond Aquaculture. Research and Development Series No. 43. International Center for Aquaculture and Aquatic Environments, Alabama Agricultural Experiment Station, Auburn University, Alabama.

Daet, I. (2019). Study on culture of sea bass (Lates calcarifer, Bloch 1790) in hapa-in-pond environment. IOP Conference Series: Earth and Environmental Science 230, 012115 .

Do, X. V., \& Dang, P. T. K. (2010). Economic analysis of cropping system: The case study of Cai Lay district, Tien Giang province. Can Tho University Journal of Science 13, 113-119.

FAO-FAD (Food and Agriculture Organization-Fisheries and Aquaculture Department). (2020). Cultured Aquatic Species Information Programme - Lates calcarifer (Block, 1790).

GAA (Global Aquaculture Alliance). (2016). Global Fish Production Data \& Analysis - Global Fish Production Estimates \& Trends. Guangzhou, China: GAA.

Hajirezaee, S., Ajdari, D., Matinfar, A., Aghuzbeni. S. H. H., \& Rafiee, G. R. (2015). A preliminary study on marine culture of Asian seabass, Lates calcarifer in the coastal earthen ponds of Gwadar region, Iran. Journal of Applied Animal Research 43(3), 309-313. 
Ly, K. V., Tran, H. N., \& Le, H. V. (2016). An evaluation on the potential development of seabass model (Lates calcarifer) along the coastal provinces of the Mekong Delta area. An Giang University Journal of Science 11(3), 60-71.

Kungvankij, P., Pudadera, Jr. B. J., Tiro, Jr. L. B., \& Potesta, I. O. (1986). Biology and Culture of Seabass (Lates calcarifer). NACA Training Manual Series No. 3. Network of Aquaculture Centers in Asia (NACA), Thailand.
Nguyen, S. X. B. (2009). Evaluation of socio-economic efficiency of commercial culture of Asian seabass (Lates calcarifer) in Khanh Hoa province (Unpublished master's thesis). Nha Trang University, Khanh Hoa, Vietnam. 